\title{
Left Cardiac Ventricular Assist Device Procedure
}

National Cancer Institute

\section{Source}

National Cancer Institute. Left Cardiac Ventricular Assist Device Procedure. NCI

Thesaurus. Code C99972.

A procedure involving a mechanical pump which receives blood from the left ventricle and delivers it to the aorta. (ACC) 